\title{
Correction to: Effects of dietary hemp seed oil to sows on fatty acid profiles, nutritional and immune status of piglets
}

D. Vodolazska and C. Lauridsen ${ }^{*}$

\section{Correction to: J Anim Sci Biotechnolo} https://doi.org/10.1186/s40104-020-0429-3

In the original publication of this article [1], a figure of gene expression of Cox-2 in the Appendix 1 is missing. The correct Appendix is attached.

The original publication has been corrected.

Published online: 27 May 2020

\section{Reference}

1. Vodolazska, Lauridsen. Effects of dietary hemp seed oil to sows on fatty acid profiles, nutritional and immune status of piglets. J Anim Sci Biotechnolo. 2020;11:28 https://doi.org/10.1186/s40104-020-0429-3.

The original article can be found online at https://doi.org/10.1186/s40104020-0429-3.

* Correspondence: charlotte.lauridsen@anis.au.dk

Department of Animal Science, Faculty of Technical Sciences, Aarhus

University, Blichers Allé 20, 8830 Tjele, Denmark

(c) The Author(s). 2020 Open Access This article is licensed under a Creative Commons Attribution 4.0 International License, which permits use, sharing, adaptation, distribution and reproduction in any medium or format, as long as you give appropriate credit to the original author(s) and the source, provide a link to the Creative Commons licence, and indicate if changes were made. The images or other third party material in this article are included in the article's Creative Commons licence, unless indicated otherwise in a credit line to the material. If material is not included in the article's Creative Commons licence and your intended use is not permitted by statutory regulation or exceeds the permitted use, you will need to obtain permission directly from the copyright holder. To view a copy of this licence, visit http://creativecommons.org/licenses/by/4.0/ The Creative Commons Public Domain Dedication waiver (http://creativecommons.org/publicdomain/zero/1.0/) applies to the data made available in this article, unless otherwise stated in a credit line to the data. 


\section{Appendix 1}
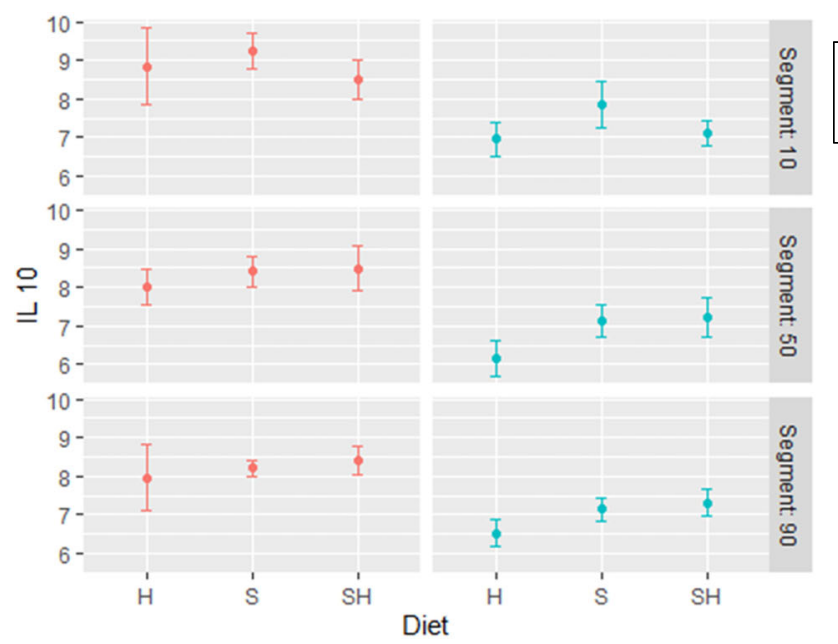

Effect of segment $(P<0.001)$

and tissue $(P<0.001)$

$\therefore$ Mucus

$\rightarrow$ Epithelium
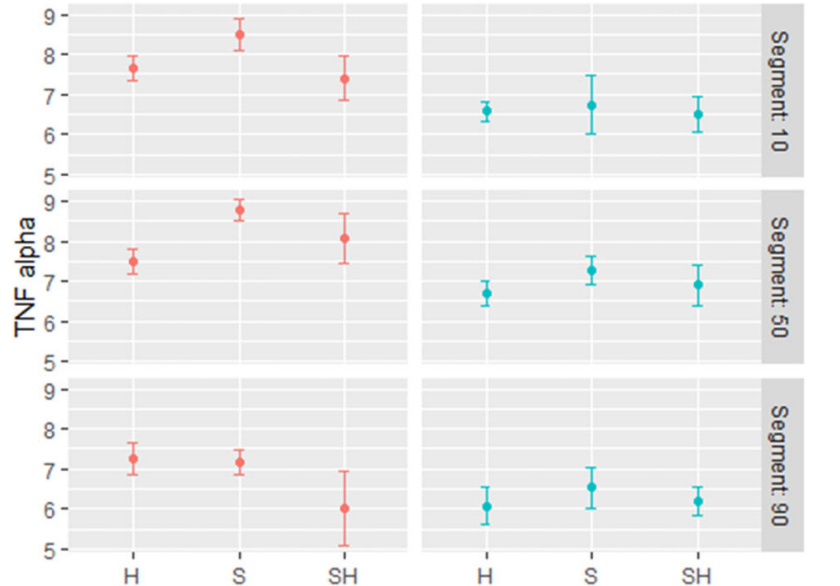

Effect of segment $(P<0.001)$

and tissue $(P=0.0008)$

Diet

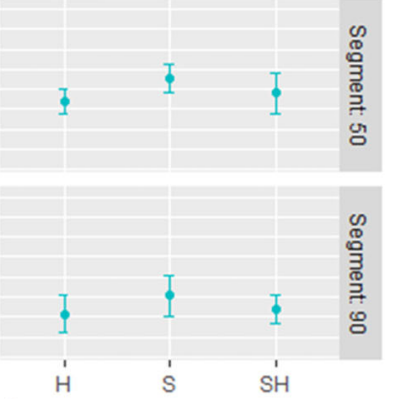

$\rightarrow$ Mucus

$\rightarrow$ Epithelium
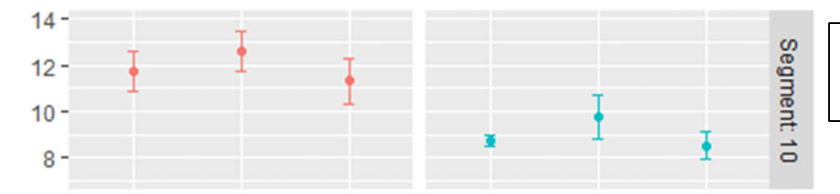

Effect of segment $(P<0.001)$

and tissue $(P<0.001)$
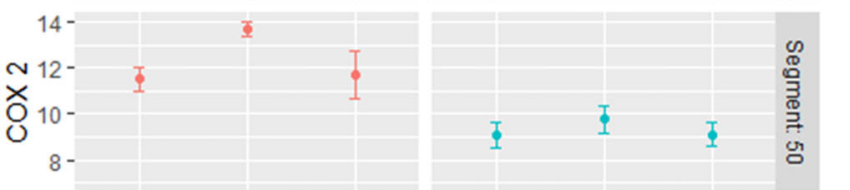

$\rightarrow$ Mucus

$\rightarrow$ Epithelium
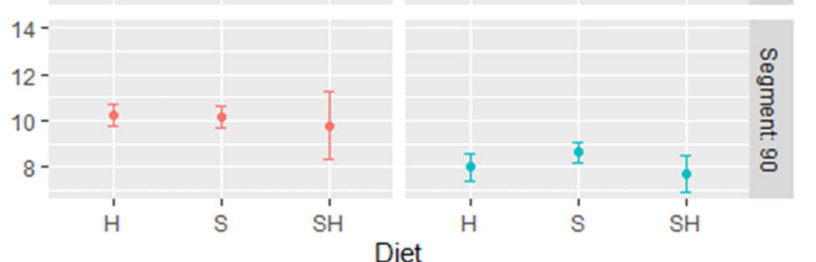

Fig. 3 Gene expression ( $\triangle C t$ ) of COX-2, IL-10, TNF- $a$ in piglets intestine. H=basal diet and hemp seed oil in ratio 95:5, HS= basal diet and mix of soybean and hemp seed oils (50:50) in ratio 95:5; S= basal diet and soybean oil in ratio 95:5; basal diet formulated according to Danish Nutrient Standards for Lactating Sows [24]. Segment $10=$ proximal part of small intestine; segment $50=$ mid part of small intestine and segment $90=$ distal part of small intestine; type of tissue =mucus layer and intestinal epithelium 